\title{
INTERRELATIONS OF PLASMA POTASSIUM CONCENTRATION, PLASMA SODIUM CONCENTRATION, ARTERIAL pH AND TOTAL EXCHANGEABLE POTASSIUM *
}

\author{
By J. LEIBMAN $\dagger$ AND I. S. EDELMAN $\ddagger$ \\ (From the Department of Medicine, University of California School of Medicine, \\ San Francisco, Calif.)
}

(Submitted for publication June 21, 1959; accepted August 26, 1959)

Accurate and quantitative definition of the factors that determine plasma potassium concentration has not yet been attained. However, important relationships have been noted between plasma potassium concentration and acid-base disturbances (1-11), acute and chronic losses of body potassium $(2,12)$ and changes in plasma sodium concentration $(13,14)$. Conversely, frequent exceptions to these individual relationships are seen. The intimate association between plasma sodium concentration and body sodium, potassium, and water suggests that an analogous multifactored control might obtain for plasma potassium concentration (15). When body potassium content is constant, changes in the plasma potassium level may reasonably be attributed to osmotic and electrochemical influences which alter the concentration gradient of potassium across the cell membrane. The status of intracellular metabolism has a major effect on this gradient, since the anoxic, damaged or glucose-depleted cell leaks potassium at an accelerated rate (16-18).

An analysis of the various determinants of plasma potassium concentration and a consideration of their possible interrelationships are of some importance. Clarification of the nature and degree of any such interrelationships may modify or verify concepts of the physiological mechanisms affecting changes in electrolyte distribution and in addition may facilitate more precise clinical interpretations.

Simultaneous measurements of total exchangeable potassium, total body water, arterial and ve-

* This work was supported by grants-in-aid from the American Heart Association, the United States Public Health Service (Grant No. H-1441), the Monterey County Heart Association and the Committee on Research of the University of California School of Medicine.

$\dagger$ Research Fellow of the American Heart Association.

$\ddagger$ During tenure as an Established Investigator of the American Heart Association. nous blood $\mathrm{pH}$ and arterial and venous plasma electrolyte concentrations were made in a heterogeneous group of chronically ill patients who had been in a steady state ${ }^{1}$ for at least two or three days before study. The correlations of plasma potassium concentration with plasma sodium concentration, arterial $\mathrm{pH}, \mathrm{pCO}_{2}$, total exchangeable potassium and various combinations of these measurements were analyzed statistically.

\section{METHODS}

Definitions. The symbols and abbreviations used in this paper are defined as follows: $K_{p}$, potassium concentration in milliequivalents per liter of arterial plasma water; $\mathrm{Na}_{\mathrm{p}}$, sodium concentration in milliequivalents per liter of arterial plasma water; $\mathrm{Cl}_{\mathbf{p}}$, chloride concentration in millequivalents per liter of arterial plasma; $\left(\mathrm{CO}_{2}\right)_{\mathrm{p}}$ total $\mathrm{CO}_{2}$ content in millimoles per liter of arterial plasma; $\mathrm{pCO}_{2}$, partial pressure of $\mathrm{CO}_{2}$ in millimeters $\mathrm{Hg}$ in arterial plasma; $\mathrm{H}_{\mathrm{a}}$, hydrogen ion concentration in Moles $\times 10^{-8}$ per liter of arterial blood (to simplify calculation, the factor of $10^{-8}$ is omitted) ; $\mathrm{K}_{\mathrm{e}}$, total exchangeable potassium in milliequivalents; TBW, total body water in liters; DBW, dry body weight in kilograms calculated as body weight minus total body water; $\mathrm{D}_{2} \mathrm{O}$, deuterium oxide; THO, tritiated water.

Seventy-four patients were studied. The age, sex, state of hydration, and clinical diagnosis are summarized in Table I. The patients were selected to provide a wide range of plasma potassium concentrations and $\mathrm{pH}$ values; the group was also limited to lean or malnourished subjects to eliminate as far as possible the distorting effect of body fat in interindividual comparisons of $K_{e}$. In 23 subjects who were seriously ill the investigation was confined to measurements of blood $\mathrm{pH}$ and electrolyte concentrations. The group as a whole consisted of 7 patients with various types of heart disease, 15 with cirrhosis of the liver, 14 with renal disease, 21 with pulmonary disease, 3 with gastrointestinal disease, 8 with neurological disease, and 6 with other disorders, including carcinomatosis, barbiturate intoxication, and senility. Thirty-eight of these patients were edematous.

The patients were classified as far as possible accord-

\footnotetext{
${ }^{1}$ No significant changes in clinical status, renal or
} respiratory function or plasma electrolyte concentrations. 
ing to the four major categories of acid-base disturbance. Normal $\mathrm{pH}$ in this laboratory for arterial blood is $7.43 \pm$ 0.02 ; the normal $\left(\mathrm{CO}_{2}\right)_{\mathrm{p}}$ is $25.6 \pm 2.4 \mathrm{mMoles}$ per $\mathrm{L}$. Acidotic patients, i.e., those with arterial $\mathrm{pH}$ less than 7.41 , were designated under respiratory acidosis if $\left(\mathrm{CO}_{2}\right)_{\mathrm{p}}$ was greater than $28.0 \mathrm{mMoles}$ per L., and under metabolic acidosis if $\left(\mathrm{CO}_{2}\right)_{\mathfrak{p}}$ was less than 23 mMoles per L. Alkalotic patients, i.e., those with arterial $\mathrm{pH}$ greater than 7.45 , were listed under respiratory alkalosis if $\left(\mathrm{CO}_{2}\right)_{\mathrm{p}}$ was less than $23 \mathrm{mMoles}$ per L. and under metabolic alkalosis if $\left(\mathrm{CO}_{2}\right)_{\mathrm{p}}$ was greater than 28 mMoles per L. In seven cases in which normal arterial $\mathrm{pH}$ was associated with abnormal $\left(\mathrm{CO}_{2}\right)_{\mathrm{p}}$ the findings were interpreted in the light of the clinical status. Four patients with unidentifiable acid-base disturbance, together with 16 cases in which data were insufficient and five patients in whom both arterial $\mathrm{pH}$ and $\left(\mathrm{CO}_{2}\right)_{\mathrm{p}}$ were normal were listed in the unclassified category. No attempt has been made to separate compensated from uncompensated cases. None of the experimental subjects
TABLE I

Summary of clinical data

\begin{tabular}{|c|c|c|c|c|c|c|}
\hline Disease & & Male & Female & $\underset{\text { range }}{\text { Age }}$ & $\begin{array}{l}\text { Weight } \\
\text { range }\end{array}$ & $\begin{array}{c}\text { Transu } \\
\text { dates }\end{array}$ \\
\hline \multicolumn{4}{|c|}{ (No. of cases) } & $y r$. & $K g$. & \\
\hline Heart & $(7)$ & 6 & 1 & $40-74$ & $33-80$ & 7 \\
\hline Kidney & (14) & 11 & 3 & $17-75$ & $39-80$ & 7 \\
\hline Gastrointestinal & (3) & 2 & 1 & $35-40$ & $40-56$ & 0 \\
\hline Liver & (15) & 7 & 8 & $35-86$ & $39-72$ & 13 \\
\hline Lung & (21) & 19 & 2 & $25-82$ & $39-68$ & 5 \\
\hline Neurological & $(8)$ & 6 & 2 & $25-80$ & $42-67$ & 4 \\
\hline Miscellaneous & (6) & 4 & 2 & $40-72$ & $46-50$ & 2 \\
\hline
\end{tabular}

was treated with carbonic anhydrase inhibitors during the period of study.

All subjects were given an analyzed diet containing $10 \mathrm{mEq}$. sodium and $21 \mathrm{mEq}$. potassium daily during the period of study. Food and fluid were withheld for the period of $\mathrm{D}_{2} \mathrm{O}$ or THO equilibration.

TABLE II

Summary of laboratory data: plasma values

\begin{tabular}{|c|c|c|c|c|c|c|c|}
\hline \multirow[b]{2}{*}{ Patient } & \multirow[b]{2}{*}{$\mathrm{K}_{\mathrm{p}} *$} & \multirow[b]{2}{*}{$\mathrm{Nap}_{\mathrm{p}} *$} & \multirow[b]{2}{*}{$\mathrm{Cl}_{\mathrm{p}} *$} & \multirow[b]{2}{*}{$\left(\mathrm{CO}_{2}\right)_{\mathrm{p}} *$} & \multicolumn{2}{|c|}{$\mathrm{pH}$} & \multirow[b]{2}{*}{$\mathrm{pCO}_{2} *$} \\
\hline & & & & & Arterial & Venous & \\
\hline $\begin{array}{l}\text { No. } \\
\text { Metab }\end{array}$ & $\begin{array}{l}m E q . / L . \\
\text { plasma water } \\
\text { cidosis }\end{array}$ & $\begin{array}{l}m E q . / L . \\
\text { plasma water }\end{array}$ & $\underset{\text { plasma }}{m E q . / L .}$ & $\underset{\text { plasma }}{\text { mMoles } / L .}$ & & & $m m . H g$ \\
\hline $\begin{array}{l}14 \\
17 \\
19 \\
20 \\
25 \\
31 \\
35 \\
37 \\
39 \\
40 \\
42 \\
55 \\
56 \\
61 \\
66 \\
69 \\
71 \\
74\end{array}$ & $\begin{array}{l}4.65 \\
5.72 \\
5.32 \\
4.70 \\
5.84 \\
5.12 \\
6.53 \\
2.98 \\
4.76 \\
6.16 \\
4.74 \\
3.51 \\
5.34 \\
4.08 \\
5.60 \\
5.15 \\
5.48 \\
4.35\end{array}$ & $\begin{array}{l}172.5 \\
140.2 \\
153.1 \\
150.1 \\
143.9 \\
141.0 \\
114.7 \\
154.2 \\
142.9 \\
127.1 \\
157.2 \\
131.6 \\
146.0 \\
148.6 \\
135.4 \\
143.9 \\
127.5 \\
132.8\end{array}$ & $\begin{array}{r}105.7 \\
116.8 \\
99.2 \\
109.0 \\
115.0 \\
88.8 \\
116.6 \\
98.5\end{array}$ & $\begin{array}{r}20.9 \\
11.6 \\
9.8 \\
16.8 \\
8.1 \\
10.2 \\
14.4 \\
6.9 \\
17.6 \\
18.4 \\
6.6 \\
15.2 \\
22.3 \\
18.9 \\
20.4 \\
10.3 \\
19.7 \\
18.3\end{array}$ & $\begin{array}{l}7.37 \\
7.36 \\
7.32 \\
7.40 \\
7.15 \\
7.28 \\
7.40 \\
7.29 \\
7.34 \\
7.35 \\
7.15 \\
7.40 \\
7.36 \\
7.37 \\
7.39 \\
7.23 \\
7.35 \\
7.28\end{array}$ & $\begin{array}{l}7.24 \\
7.36 \\
7.24 \\
7.35 \\
7.26 \\
7.11 \\
7.33 \\
7.36 \\
7.33\end{array}$ & $\begin{array}{l}36.0 \\
21.5 \\
20.0 \\
28.0 \\
25.0 \\
23.5 \\
24.0 \\
15.0 \\
35.5 \\
35.0 \\
19.5 \\
25.0 \\
40.0 \\
32.5 \\
35.2 \\
24.5 \\
36.0 \\
39.5\end{array}$ \\
\hline \multicolumn{8}{|c|}{ Metabolic alkalosis } \\
\hline $\begin{array}{r}5 \\
6 \\
9 \\
10 \\
13 \\
15 \\
44 \\
46 \\
47 \\
49 \\
54 \\
62 \\
63 \\
72\end{array}$ & $\begin{array}{l}4.58 \\
3.55 \\
3.74 \\
3.08 \\
5.12 \\
2.89 \\
3.11 \\
2.34 \\
2.54 \\
2.78 \\
3.46 \\
4.26 \\
3.57 \\
2.56\end{array}$ & $\begin{array}{l}141.2 \\
139.8 \\
161.6 \\
140.8 \\
143.2 \\
139.0 \\
146.6 \\
142.8 \\
144.0 \\
150.7 \\
135.5 \\
146.8 \\
158.3 \\
134.0\end{array}$ & $\begin{array}{r}94.8 \\
96.7 \\
92.1 \\
91.4 \\
95.2 \\
101.5 \\
100.0 \\
\\
89.4 \\
103.0 \\
100.0 \\
91.8\end{array}$ & $\begin{array}{l}34.4 \\
29.6 \\
34.5 \\
35.8 \\
30.4 \\
29.3 \\
28.1 \\
33.2 \\
30.8 \\
31.7 \\
29.4 \\
29.8 \\
34.9 \\
30.5\end{array}$ & $\begin{array}{l}7.44 \\
7.55 \\
7.46 \\
7.50 \\
7.47 \\
7.54 \\
7.52 \\
7.56 \\
7.49 \\
7.54 \\
7.53 \\
7.46 \\
7.49 \\
7.53\end{array}$ & $\begin{array}{l}7.45 \\
7.51 \\
7.49 \\
7.50 \\
7.47 \\
7.42 \\
7.44 \\
7.49\end{array}$ & $\begin{array}{l}51.0 \\
35.5 \\
49.0 \\
46.0 \\
42.2 \\
35.5 \\
36.0 \\
38.0 \\
41.0 \\
38.0 \\
37.5 \\
42.5 \\
46.5 \\
37.5\end{array}$ \\
\hline
\end{tabular}

${ }^{*} \mathrm{~K}_{\mathrm{p}}=$ potassium concentration; $\mathrm{Na}_{\mathrm{p}}=$ sodium concentration; $\mathrm{Cl}_{\mathrm{p}}=$ chloride concentration; $\left(\mathrm{CO}_{2}\right)_{\mathrm{p}}=$ total $\mathrm{CO}_{2}$ content; $\mathrm{pCO}_{2}=$ partial pressure of $\mathrm{CO}_{2}$. 
TABLE II-Continued

\begin{tabular}{|c|c|c|c|c|c|c|c|}
\hline \multirow[b]{2}{*}{ Patient } & \multirow[b]{2}{*}{$\mathbf{K}_{\mathbf{p}}^{*}$} & \multirow[b]{2}{*}{$\mathrm{Na}_{\mathrm{p}}{ }^{*}$} & \multirow[b]{2}{*}{$\mathrm{Cl}_{\mathrm{p}}^{*}$} & \multirow[b]{2}{*}{$\left(\mathrm{CO}_{2}\right)_{0}^{*}$} & \multicolumn{2}{|c|}{$\mathrm{pH}$} & \multirow[b]{2}{*}{$\mathrm{pCO}_{2}^{*}$} \\
\hline & & & & & Arterial & Venous & \\
\hline \multicolumn{7}{|c|}{ Respiratory alkalosis } & $m m \cdot \mathrm{Hg}$ \\
\hline $\begin{array}{r}\mathbf{4} \\
\mathbf{1 1} \\
\mathbf{3 8} \\
\mathbf{5 1} \\
\mathbf{5 3} \\
\mathbf{5 7} \\
\mathbf{5 9}\end{array}$ & $\begin{array}{l}3.95 \\
4.18 \\
6.15 \\
5.01 \\
1.93 \\
2.87 \\
4.93\end{array}$ & $\begin{array}{l}131.0 \\
139.5 \\
125.7 \\
148.5 \\
143.9 \\
145.6 \\
142.1\end{array}$ & $\begin{array}{r}115.8 \\
109.3 \\
95.7 \\
106.1\end{array}$ & $\begin{array}{l}22.6 \\
18.8 \\
15.8 \\
17.5 \\
14.3 \\
22.6 \\
20.8\end{array}$ & $\begin{array}{l}7.48 \\
7.59 \\
7.48 \\
7.54 \\
7.51 \\
7.48 \\
7.47\end{array}$ & $\begin{array}{l}7.45 \\
7.51 \\
7.42 \\
7.44 \\
7.41\end{array}$ & $\begin{array}{l}30.5 \\
20.0 \\
23.0 \\
21.0 \\
19.0 \\
33.5 \\
29.0\end{array}$ \\
\hline \multicolumn{8}{|c|}{ Respiratory acidosis } \\
\hline $\begin{array}{r}1 \\
2 \\
3 \\
7 \\
16 \\
41 \\
52 \\
58 \\
70 \\
73\end{array}$ & $\begin{array}{l}4.57 \\
4.82 \\
4.25 \\
4.37 \\
4.41 \\
5.42 \\
4.85 \\
4.28 \\
4.31 \\
5.58\end{array}$ & $\begin{array}{l}144.7 \\
141.9 \\
146.9 \\
144.3 \\
146.2 \\
140.8 \\
143.9 \\
141.8 \\
142.8 \\
139.2\end{array}$ & $\begin{array}{r}92.3 \\
98.3 \\
99.3 \\
98.2 \\
85.1 \\
100.0 \\
100.0 \\
103.5 \\
101.6\end{array}$ & $\begin{array}{l}26.3 \\
32.0 \\
32.0 \\
28.5 \\
33.3 \\
45.2 \\
35.8 \\
28.8 \\
30.9 \\
28.6\end{array}$ & $\begin{array}{l}7.25 \\
7.37 \\
7.29 \\
7.41 \\
7.43 \\
7.39 \\
7.42 \\
7.40 \\
7.37 \\
7.42\end{array}$ & $\begin{array}{l}7.37 \\
7.37 \\
7.29 \\
7.41\end{array}$ & $\begin{array}{l}59.0 \\
54.5 \\
66.0 \\
47.5 \\
50.0 \\
74.5 \\
55.0 \\
47.0 \\
53.0 \\
44.5\end{array}$ \\
\hline \multicolumn{8}{|c|}{ Unclassified } \\
\hline $\begin{array}{l}8 \\
12 \\
18 \\
21 \\
22 \\
23 \\
24 \\
26 \\
27 \\
28 \\
29 \\
30 \\
32 \\
33 \\
34 \\
36 \\
43 \\
45 \\
48 \\
50 \\
60 \\
64 \\
65 \\
67 \\
68\end{array}$ & $\begin{array}{l}4.97 \\
3.58 \\
4.02 \\
4.52 \\
4.50 \\
3.78 \\
2.75 \\
4.43 \\
3.38 \\
4.67 \\
4.28 \\
6.68 \\
5.11 \\
4.62 \\
4.42 \\
4.80 \\
5.00 \\
4.12 \\
5.20 \\
4.87 \\
3.11 \\
2.60 \\
5.17 \\
3.81 \\
4.62\end{array}$ & $\begin{array}{l}140.1 \\
140.3 \\
142.5 \\
141.1 \\
148.5 \\
142.5 \\
134.9 \\
141.4 \\
132.6 \\
146.6 \\
151.9 \\
137.5 \\
142.9 \\
136.0 \\
139.0 \\
148.8 \\
139.5 \\
144.2 \\
141.9 \\
142.5 \\
138.6 \\
141.3 \\
136.3 \\
141.0\end{array}$ & $\begin{array}{r}105.3 \\
101.0 \\
100.2 \\
97.5 \\
102.7 \\
87.5 \\
101.0 \\
97.7 \\
104.1\end{array}$ & $\begin{array}{l}26.4 \\
25.3 \\
22.2 \\
29.1 \\
25.7 \\
24.3\end{array}$ & $\begin{array}{l}7.45 \\
7.45 \\
7.52 \\
7.44 \\
7.39 \\
7.48 \\
7.49 \\
7.44 \\
7.56 \\
7.47 \\
7.45 \\
7.27 \\
7.44 \\
7.46 \\
7.56 \\
7.44 \\
7.44 \\
7.44 \\
7.45 \\
7.39 \\
7.48 \\
7.51 \\
7.45 \\
7.50 \\
7.38\end{array}$ & $\begin{array}{l}7.42 \\
7.25 \\
7.35 \\
7.39 \\
7.52 \\
7.38 \\
7.42 \\
7.43 \\
7.39 \\
7.33 \\
7.44 \\
7.46 \\
7.42 \\
7.42\end{array}$ & $\begin{array}{l}41.0 \\
42.0 \\
33.0 \\
41.5 \\
35.0 \\
36.0\end{array}$ \\
\hline Mean & 4.34 & 141.8 & 101.8 & 23.8 & 7.43 & 7.39 & 37.1 \\
\hline Range & $1.93-6.68$ & $114.7-172.5$ & $85.1-121.3$ & $6.9-45.2$ & $7.15-7.59$ & $7.11-7.52$ & $15.0-74.5$ \\
\hline
\end{tabular}

The sequence and technique of isotope administration and collection of urine and blood for isotope assay have been described previously $(19,20)$. Three hundred to $350 \mu \mathrm{c}$. $\mathrm{K}^{2}$, and to a few subjects 1 to $2 \mathrm{mc}$. tritium, were the maximum doses of administered radioactivity. The periods of isotope equilibration were 40 hours for $\mathrm{K}^{4}$ and six hours for $\mathrm{D}_{2} \mathrm{O}$ or THO. Blood was drawn almost simultaneously from the femoral artery and antecubital vein at the end of the $\mathrm{K}^{\text {sa }}$ equilibration period and immediately before the deuterium or tritium injec- tion. Glycolysis and clotting in these samples were inhibited by icing and heparin.

The analytical methods for isotope assay have been described previously $(19,21,22)$. Sodium and potassium were measured in dilutions of urine and plasma with a lithium internal-standard flame photometer. Plasma water was determined gravimetrically by drying $1 \mathrm{ml}$. aliquots, delivered from calibrated pipettes, at $104^{\circ} \mathrm{C}$. for 72 hours. Plasma chloride was estimated by electrometric titration (23), and total $\mathrm{CO}_{2}$ content of 
PLASMA POTASSIUM AND BODY COMPOSITION

TABLE III

Summary of laboratory data: body composition and derived values

\begin{tabular}{|c|c|c|c|c|c|c|c|}
\hline Patient & $\mathrm{K}_{0} *$ & $\begin{array}{l}\mathrm{K}_{0} / \mathbf{K g} \\
\text { body wt. }\end{array}$ & TBW* & $\begin{array}{l}\text { TBW/Kg. } \\
\text { body wt. }\end{array}$ & $\mathrm{K}_{0} / \mathrm{DBW}^{*}$ & $\mathrm{~K}_{\mathbf{0}} / \mathrm{DBW} \times \mathrm{H}_{\mathbf{a}}$ & $\frac{\mathrm{K}_{\mathrm{o}} / \mathrm{DBW} \times \mathrm{H}_{\mathbf{a}}}{\mathrm{Na}_{\mathrm{p}}{ }^{*}}$ \\
\hline \multicolumn{8}{|c|}{$\begin{array}{c}\text { No. } \\
\text { Metabolic acidosis }\end{array}$} \\
\hline $\begin{array}{l}17 \\
19 \\
20 \\
25 \\
31 \\
35 \\
39 \\
40 \\
42 \\
56 \\
61 \\
66 \\
69 \\
71 \\
74\end{array}$ & $\begin{array}{l}2,508 \\
2,164 \\
1,251 \\
2,234 \\
2,295 \\
2,012 \\
1,176 \\
2,887 \\
1,357 \\
2,975 \\
1,422 \\
1,572 \\
1,929 \\
1,707 \\
2,265\end{array}$ & $\begin{array}{l}36.8 \\
38.5 \\
34.6 \\
34.6 \\
48.8 \\
32.2 \\
23.6 \\
35.9 \\
29.8 \\
43.1 \\
24.6 \\
34.2 \\
36.1 \\
31.8 \\
32.1\end{array}$ & $\begin{array}{l}45.9 \\
39.9 \\
18.7 \\
33.2 \\
30.7 \\
47.6 \\
28.2 \\
55.5 \\
29.0 \\
49.9 \\
44.3 \\
28.1 \\
27.8 \\
38.0 \\
40.9\end{array}$ & $\begin{array}{l}67.3 \\
71.1 \\
51.9 \\
51.4 \\
65.2 \\
76.4 \\
55.8 \\
69.0 \\
63.7 \\
72.2 \\
76.8 \\
61.1 \\
52.1 \\
70.8 \\
57.9\end{array}$ & $\begin{array}{r}112.5 \\
133.6 \\
71.9 \\
71.4 \\
140.8 \\
136.9 \\
53.5 \\
115.9 \\
82.2 \\
154.9 \\
106.1 \\
88.1 \\
75.5 \\
109.2 \\
76.4\end{array}$ & $\begin{array}{l}490.5 \\
639.9 \\
286.1 \\
505.5 \\
739.2 \\
532.5 \\
244.4 \\
518.1 \\
582.0 \\
676.9 \\
453.0 \\
358.6 \\
444.7 \\
488.1 \\
401.1\end{array}$ & $\begin{array}{l}3.50 \\
4.18 \\
1.90 \\
3.51 \\
5.24 \\
4.64 \\
1.71 \\
4.08 \\
3.70 \\
4.64 \\
3.05 \\
2.65 \\
3.29 \\
3.83 \\
3.02\end{array}$ \\
\hline \multicolumn{8}{|c|}{ Metabolic alkalosis } \\
\hline $\begin{array}{r}5 \\
6 \\
13 \\
15 \\
44 \\
47 \\
49 \\
54 \\
62 \\
63 \\
72\end{array}$ & $\begin{array}{l}2,165 \\
1,529 \\
1,893 \\
1,381 \\
1,973 \\
1,751 \\
1,213 \\
2,817 \\
1,318 \\
2,549 \\
1,492\end{array}$ & $\begin{array}{l}35.8 \\
30.7 \\
35.9 \\
24.0 \\
39.6 \\
29.9 \\
23.0 \\
39.3 \\
30.9 \\
45.2 \\
28.7\end{array}$ & $\begin{array}{l}38.6 \\
30.9 \\
28.6 \\
36.0 \\
32.5 \\
31.6 \\
26.7 \\
49.4 \\
24.7 \\
33.9 \\
26.5\end{array}$ & $\begin{array}{l}63.7 \\
62.1 \\
54.1 \\
62.5 \\
65.3 \\
53.9 \\
50.6 \\
69.0 \\
57.7 \\
60.1 \\
51.0\end{array}$ & $\begin{array}{r}98.4 \\
80.9 \\
78.1 \\
64.2 \\
114.2 \\
64.9 \\
46.7 \\
126.9 \\
73.0 \\
113.2 \\
58.5\end{array}$ & $\begin{array}{l}375.2 \\
228.1 \\
264.8 \\
184.9 \\
344.9 \\
210.3 \\
134.5 \\
399.7 \\
253.3 \\
366.8 \\
172.6\end{array}$ & $\begin{array}{l}2.66 \\
1.63 \\
1.85 \\
1.33 \\
2.38 \\
1.46 \\
0.89 \\
2.95 \\
1.73 \\
2.32 \\
1.28\end{array}$ \\
\hline \multicolumn{8}{|c|}{ Respiratory alkalosis } \\
\hline $\begin{array}{r}4 \\
51 \\
53 \\
57 \\
59\end{array}$ & $\begin{array}{r}1,934 \\
869 \\
1,623 \\
1,725 \\
2,261\end{array}$ & $\begin{array}{l}41.7 \\
27.7 \\
33.7 \\
34.5 \\
28.5\end{array}$ & $\begin{array}{l}28.9 \\
20.3 \\
28.3 \\
29.4 \\
49.6\end{array}$ & $\begin{array}{l}62.2 \\
64.8 \\
58.7 \\
58.7 \\
62.4\end{array}$ & $\begin{array}{r}110.3 \\
78.3 \\
81.6 \\
83.6 \\
75.7\end{array}$ & $\begin{array}{l}365.1 \\
225.5 \\
252.1 \\
276.7 \\
256.6\end{array}$ & $\begin{array}{l}2.79 \\
1.52 \\
1.75 \\
1.90 \\
1.81\end{array}$ \\
\hline \multicolumn{8}{|c|}{ Respiratory acidosis } \\
\hline $\begin{array}{r}1 \\
2 \\
16 \\
58 \\
70 \\
73\end{array}$ & $\begin{array}{l}1,859 \\
2,201 \\
1,860 \\
2,036 \\
1,914 \\
1,102\end{array}$ & $\begin{array}{l}34.4 \\
42.1 \\
38.8 \\
32.7 \\
49.0 \\
33.2\end{array}$ & $\begin{array}{l}27.7 \\
33.7 \\
28.7 \\
34.9 \\
25.3 \\
21.2\end{array}$ & $\begin{array}{l}51.1 \\
64.5 \\
59.7 \\
55.9 \\
64.7 \\
63.9\end{array}$ & $\begin{array}{r}70.3 \\
118.3 \\
96.4 \\
74.2 \\
138.7 \\
91.8\end{array}$ & $\begin{array}{l}395.1 \\
505.1 \\
358.6 \\
295.3 \\
592.2 \\
348.8\end{array}$ & $\begin{array}{l}2.73 \\
3.56 \\
2.45 \\
2.08 \\
4.15 \\
2.51\end{array}$ \\
\hline \multicolumn{8}{|c|}{ Unclassified } \\
\hline $\begin{array}{r}8 \\
12 \\
23 \\
27 \\
28 \\
43 \\
45 \\
48 \\
50 \\
60 \\
64 \\
65 \\
67 \\
68\end{array}$ & $\begin{array}{l}1,092 \\
1,887 \\
1,054 \\
1,469 \\
2,214 \\
1,306 \\
1,338 \\
1,894 \\
1,203 \\
1,545 \\
1,162 \\
1,518 \\
1,607 \\
2,049\end{array}$ & $\begin{array}{l}27.9 \\
39.9 \\
23.2 \\
25.7 \\
49.6 \\
33.2 \\
21.2 \\
38.7 \\
24.4 \\
29.9 \\
29.7 \\
32.4 \\
34.0 \\
30.9\end{array}$ & $\begin{array}{l}28.0 \\
27.7 \\
25.3 \\
28.2 \\
30.0 \\
26.7 \\
39.6 \\
26.4 \\
28.7 \\
32.4 \\
20.5 \\
27.7 \\
26.3 \\
33.0\end{array}$ & $\begin{array}{l}71.7 \\
58.6 \\
55.5 \\
49.3 \\
67.5 \\
68.0 \\
62.7 \\
54.0 \\
58.1 \\
62.7 \\
52.4 \\
59.1 \\
55.5 \\
49.7\end{array}$ & $\begin{array}{r}97.5 \\
96.3 \\
52.2 \\
50.7 \\
151.6 \\
104.0 \\
56.7 \\
84.2 \\
58.3 \\
80.3 \\
62.4 \\
79.3 \\
76.5 \\
61.3\end{array}$ & $\begin{array}{l}346.1 \\
341.9 \\
172.8 \\
139.4 \\
513.9 \\
377.5 \\
205.9 \\
292.2 \\
237.3 \\
265.8 \\
192.8 \\
281.5 \\
241.7 \\
255.6\end{array}$ & $\begin{array}{l}2.47 \\
2.44 \\
1.21 \\
1.05 \\
3.51 \\
2.53 \\
1.49 \\
2.03 \\
1.67 \\
1.87 \\
1.39 \\
1.99 \\
1.77 \\
1.81\end{array}$ \\
\hline $\begin{array}{l}\text { Mean } \\
\text { Range }\end{array}$ & $\begin{array}{c}1,776 \\
869-2,975\end{array}$ & $\begin{array}{c}33.7 \\
21.2-49.6\end{array}$ & $\begin{array}{c}32.3 \\
18.7-55.5\end{array}$ & $\begin{array}{c}60.9 \\
49.3-76.8\end{array}$ & $\begin{array}{c}89.8 \\
46.7-154.9\end{array}$ & $\begin{array}{c}353.6 \\
134.5-739.2\end{array}$ & $\begin{array}{c}2.51 \\
0.89-5.24\end{array}$ \\
\hline
\end{tabular}

${ }^{*} \mathrm{~K}_{\mathrm{e}}=$ total exchangeable potassium $; \mathrm{TBW}=$ total body water $; \mathrm{DBW}=$ dry body weight $; \mathrm{H}_{\mathrm{a}}=$ hydrogen ion concentration; $\mathrm{Na}_{\mathrm{p}}=$ sodium concentration. 
arterial plasma was determined by Van Slyke's manometric method (24). The $\mathrm{pCO}_{2}$ was estimated from the Singer-Hastings nomogram (25). Arterial and venous blood $\mathrm{pH}$ were measured at $37^{\circ} \mathrm{C}$. with a Beckman model GS pH meter, calibrated with buffer standards prepared from high purity salts provided by the National Bureau of Standards. The latter measurements were made within 30 minutes of sampling; previous experiments in this laboratory had indicated that iced specimens showed no change in $\mathrm{pH}$ for at least 60 minutes after sampling. All chemical determinations were done in duplicate or triplicate.

Calculations, statistics, and analytical error. . Standard formulas were used in calculating specific activities, $K_{0}$. and TBW, including corrections for isotope excretion in the urine $(21,26)$. Whenever a 24 hour interval elapsed between $K_{e}$ and TBW determinations, the $K_{e}$ was corrected to the time of TBW measurement by metabolic balance for potassium by using measured intake and urinary losses. The plasma potassium and sodium concentrations, expressed in milliequivalents per liter of plasma water, were derived from the measured plasma sodium and potassium concentrations and plasma water content.

Conventional statistical equations were used to calculate standard deviations (S.D.) and correlation coefficients $(r)$. The probability ( $p$ ) of a correlation coeffcient being obtained by chance was evaluated by the " $t$ " test (27).

\section{RESULTS}

The data obtained in this study are listed in Tables II and III. There were 18 subjects with metabolic acidosis, 14 with metabolic alkalosis, 7 with respiratory alkalosis, 10 with respiratory acidosis, and 25 with normal acid-base status or without readily identifiable acid-base disturbance. The $\mathrm{K}_{\mathrm{p}}$ varied from 1.93 to $6.68 \mathrm{mEq}$. per $\mathrm{L}$. of plasma water, $\mathrm{Na}_{\mathbf{p}}$ from 114.7 to $172.5 \mathrm{mEq}$. per L. of plasma water, $\mathrm{Cl}_{\mathrm{p}}$ from 85.1 to $121.3 \mathrm{mEq}$. per L. of plasma, arterial blood $\mathrm{pH}$ from 7.15 to 7.59 units, venous blood $\mathrm{pH}$ from 7.11 to 7.51 and $\mathrm{pCO}_{2}$ from 15.0 to $74.5 \mathrm{~mm}$. $\mathrm{Hg}$. The range of body composition values was also quite wide: TBW varied from 49.3 to 76.8 per cent of body

TABLE IV

Relationship between plasma potassium concentration and arterial $\mathrm{pH}$

\begin{tabular}{ccc}
\hline & \multicolumn{2}{c}{ Plasma potassium concentration } \\
\cline { 2 - 3 } pH range & \multicolumn{2}{c}{ MEq./L. plasma water } \\
\cline { 2 - 3 } & & S.D. \\
\hline $7.14-7.36$ & 5.10 & \pm 0.89 \\
$7.37-7.46$ & 4.66 & \pm 0.50 \\
$7.47-7.60$ & 3.58 & \pm 1.04 \\
\hline
\end{tabular}

weight; $\mathrm{K}_{\mathrm{e}}$ ranged from 21.2 to $49.6 \mathrm{mEq}$. per $\mathrm{Kg}$. of body weight and from 46.7 to $154.9 \mathrm{mEq}$. per $\mathrm{Kg}$. of dry body weight.

\section{Plasma sodium concentration and plasma potas- sium concentration}

The lowered intracellular potassium content frequently noted in such states as congestive heart failure is almost invariably associated with increased intracellular sodium concentration; this has been demonstrated in muscle (28-30) and in erythrocytes $(31,32)$. Hyponatremic and sodium retentive states have been reported to be associated with diminished renal excretion of potassium and titratable acid; this has been attributed to excessive proximal resorption of sodium, with consequent diminution in the amount of potassium secreted by exchange with sodium in the distal tubule (33). In dogs, however, the tendency to develop hyperkalemia in association with hyponatremia and sodium depletion could not be explained by renal retention of potassium (13). Conversely, administration of potassium to hyponatremic subjects has resulted in elevation of serum sodium levels (34), perhaps as a result of extrusion of sodium from potassium-depleted cells. The multiple determinants of the plasma sodium concentration and its apparent independence of extracellular $\mathrm{pH}$, however, render unlikely any significant direct correlation between $\mathrm{K}_{\mathrm{p}}$ and $\mathrm{Na}_{\mathrm{p}}$ (15). The correlation between $\mathrm{K}_{\mathrm{p}}$ and $\mathrm{Na}_{\mathrm{p}}(\mathrm{r}=$ -0.22 ) indicates that $K_{p}$ tends to vary independently of $\mathrm{Na}_{\mathrm{p}}$ or plasma osmolality. No significant difference in this correlation was found in the individual subgroups with either metabolic or respiratory acid-base disturbances (see Table V).

\section{Plasma potassium concentration and extracellular $p H$}

Numerous observations have confirmed the inverse relationship between the plasma potassium level and extracellular $\mathrm{pH}$. The in vitro demonstration that acidification of the nutrient medium with mineral acid induced extracellular migration of potassium (35) led to experiments in nephrectomized animals subjected to acid and alkaline loads (36-39), artificial induction of respiratory acidosis and alkalosis (3-11) and infusion of acid and alkaline loads into humans (1). A direct re- 


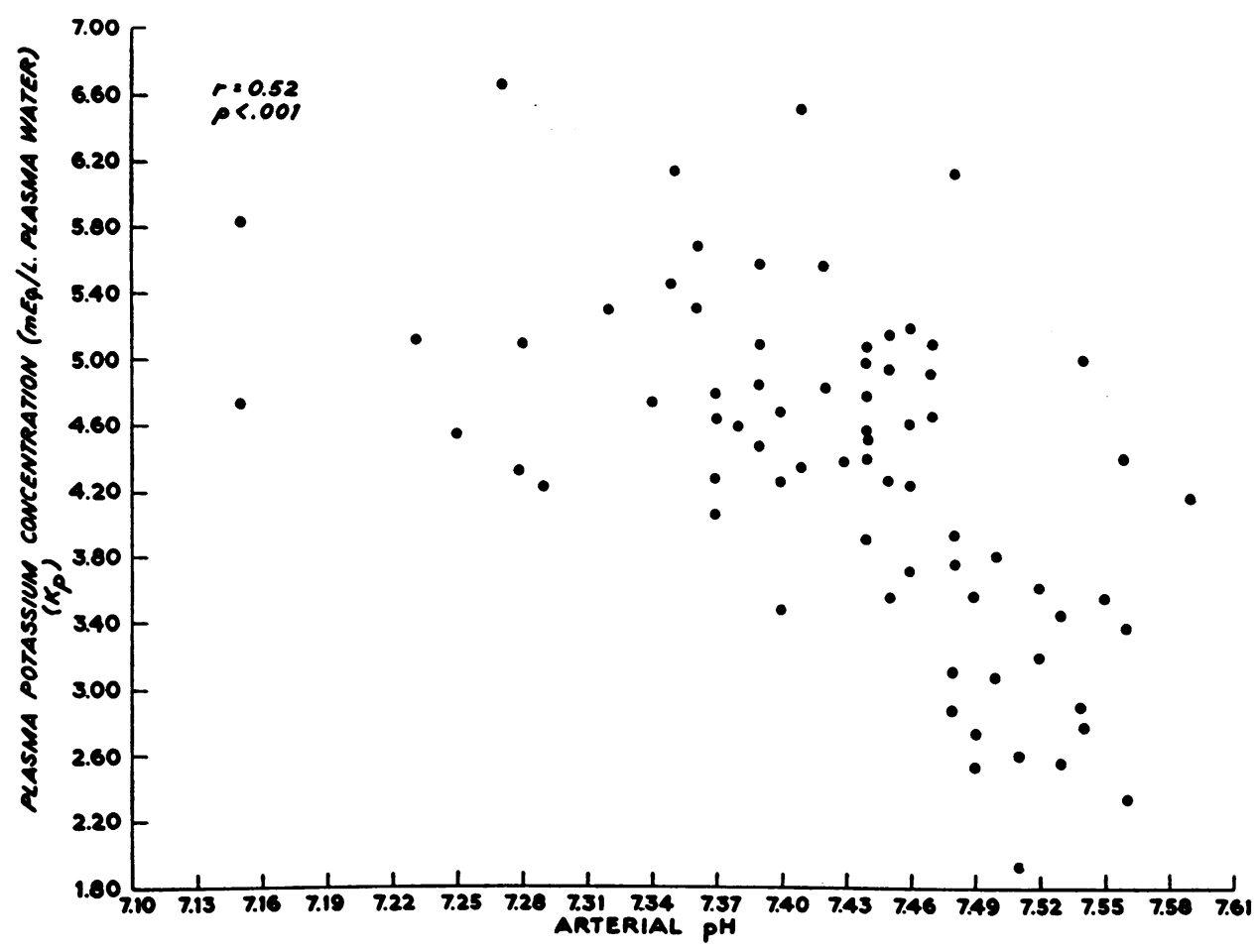

Fig. 1. Relation between Plasma Potassium Concentration and Arterial pH

lationship between hyperkalemia and acidosis and between hypokalemia and alkalosis without accompanying changes in body potassium content seems well established. The mean values for $\mathrm{K}_{\mathrm{p}}$ according to $\mathrm{pH}_{\mathrm{a}}$ subgroups, as summarized in Table IV, verify this trend. However, these are by no means invariable associations. Early respiratory alkalosis and the period immediately following respiratory acidosis have been reported to be associated with initial or further elevations of $\mathrm{K}_{\mathrm{p}}$, ascribed either to splanchnic release of potassium or to epinephrine effect $(9,10,40,41)$. Respiratory alterations of acid-base balance probably involve different buffering mechanisms than metabolic disturbances, i.e., the buffer capacity of the extracellular fluids is usually increased with respiratory acidosis and decreased with metabolic acidosis, whereas the converse obtains in respiratory alkalosis and metabolic alkalosis. Furthermore, the nature of the metabolic disturbance seems to influence differentially the accompanying ionic redistributions $(42,43)$. Clinically, both alkalosis and acidosis often are not associated with significant deviations of plasma potassium level from the normal. These exceptions to the correspondence between $\mathrm{K}_{\mathrm{p}}$ and extracellular $\mathrm{pH}$ attest to the importance of other regulatory factors. In this study the correlation between $K_{p}$ and $\mathrm{pH}$ of extracellular fluid as represented by arterial blood was significant, $r=-0.52(p<$ 0.001 ) (see Figure 1 and Table V). If the cases are limited to those with $\mathrm{pH}>7.30$, then $\mathrm{r}=$ -0.60 . A still higher correlation, $r=-0.64$, was found within the category of metabolic acidbase disturbances, while, surprisingly, in the respiratory subgroup, $r=-0.16$. No significant difference in correlation was found with venous blood $\mathrm{pH}$. The influence of changes in $\mathrm{pCO}_{2}$ on $\mathrm{K}_{\mathrm{p}}$ proved to be negligible; for the entire group, there was no correlation at all, $\mathrm{r}=-0.03$. In the metabolic disturbance subgroup a minor negative correlation was noted between $K_{p}$ and $\mathrm{pCO}_{2}, \mathrm{r}=-0.36$; the respiratory subgroup demonstrated a similar degree of correlation in the opposite direction, $r=0.30$.

\section{Plasma potassium concentration and body content of potassium}

Without doubt hypokalemia can be induced by loss of body potassium, if the loss is prolonged, 
TABLE V

Correlation* of plasma potassium concentration $\left(K_{p}\right)$ with plasma sodium concentration $\left(N a_{p}\right)$, plasma $\mathrm{PCO}_{2}$ and total exchangeable potassium $\left(K_{\bullet}\right)$

\begin{tabular}{|c|c|c|c|}
\hline & $\begin{array}{c}\text { All cases } \\
\mathrm{N} \dagger=51-74\end{array}$ & $\begin{array}{c}\text { Metabolic } \\
\text { acid-base } \\
\text { disturbances } \\
\mathbf{N}=26-32\end{array}$ & $\begin{array}{l}\text { Respiratory } \\
\text { acid-base } \\
\text { disturbances } \\
\mathbf{N}=11-17\end{array}$ \\
\hline $\begin{array}{l}\mathrm{K}_{\mathrm{p}} \text { vs. } \mathrm{Na}_{\mathrm{p}} \\
\mathrm{K}_{\mathrm{p}} \text { vs. } \mathrm{pCO}_{2} \ddagger \\
\mathrm{K}_{\mathrm{p}} \text { vs. } \mathrm{pH}(\mathrm{pH}>7.30)\end{array}$ & \multirow{5}{*}{$\begin{aligned} &- 0.22 \\
&- 0.03 \\
&- 0.60 \\
& 0.52 \\
&- 0.52 \\
&(p<0.001) \\
& 0.22 \\
&(p< \\
& 0.39 \\
&(p<005) \\
&(p<0.58 \\
&(p<0.001) \\
&<0.001)\end{aligned}$} & $\begin{array}{l}-0.24 \\
-0.36\end{array}$ & $\begin{array}{r}-0.20 \\
0.30\end{array}$ \\
\hline $\begin{array}{l}\mathrm{K}_{\mathrm{p}} \text { vs. } \mathrm{H}_{\mathrm{a}} \mp \\
\mathrm{K}_{\mathrm{p}} \text { vs. } \mathrm{pH}_{\mathrm{a}}\end{array}$ & & $\begin{array}{r}0.64 \\
-0.64\end{array}$ & $\begin{array}{r}0.16 \\
-0.16\end{array}$ \\
\hline $\begin{array}{l}\mathrm{K}_{\mathrm{p}} \text { vs. } \mathrm{K}_{\boldsymbol{e}} / \text { body weight } \\
\mathrm{K}_{\mathrm{p}} \text { vs. } \mathrm{K}_{\boldsymbol{e}} / \mathrm{DBW} \ddagger\end{array}$ & & 0.45 & -0.28 \\
\hline $\mathrm{K}_{\mathrm{p}}$ vs. $\mathrm{H}_{\mathrm{a}} \times \mathrm{K}_{\mathrm{e}} / \mathrm{DBW}$ & & 0.70 & 0.20 \\
\hline$K_{p}$ vs. $\frac{H_{a} \times K_{\odot} / D B W}{N a_{p}}$ & & $\left(\mathrm{p}<\begin{array}{l}0.74 \\
0.001)\end{array}\right.$ & 0.24 \\
\hline
\end{tabular}

* Correlation coefficient, $r=\frac{\Sigma[(X-\bar{X})(Y-\bar{Y})]}{\sqrt{\Sigma(X-\bar{X})^{2} \Sigma(Y-\bar{Y})^{2}}}$.

$\dagger \mathrm{N}=$ number of cases.

$\ddagger \mathrm{pCO}_{2}=$ partial pressure of $\mathrm{CO}_{2} ; \mathrm{H}_{\mathrm{a}}=$ hydrogen ion concentration; $\mathrm{DBW}=$ dry body weight.

acute or associated with stress or alkalosis (12). ence between $K_{p}$ and body potassium content as An attempt has been made to quantitate such an iso- reflected by $\mathrm{K}_{\mathrm{e}}$ determinations, however, has been lated relationship (2). No consistent correspond- demonstrated (44). As expected, the correlation

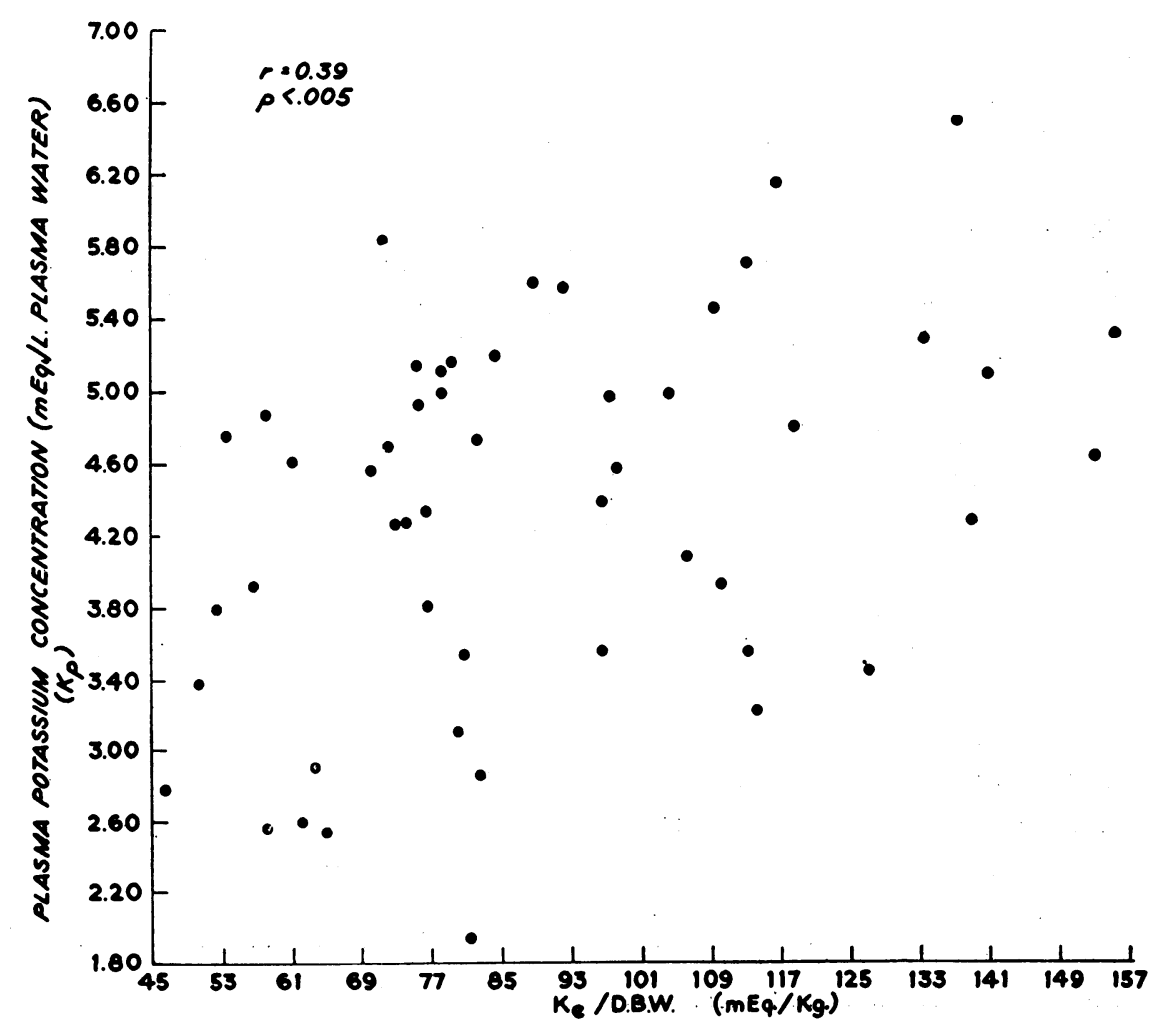

Fig. 2. Relation between Plasma Potassium Concentration ( $K_{p}$ ) and Ratio of Exchangeable Potassium to Dry Body Weight ( $\mathrm{K}_{\odot} / \mathrm{DBW}$ ) 


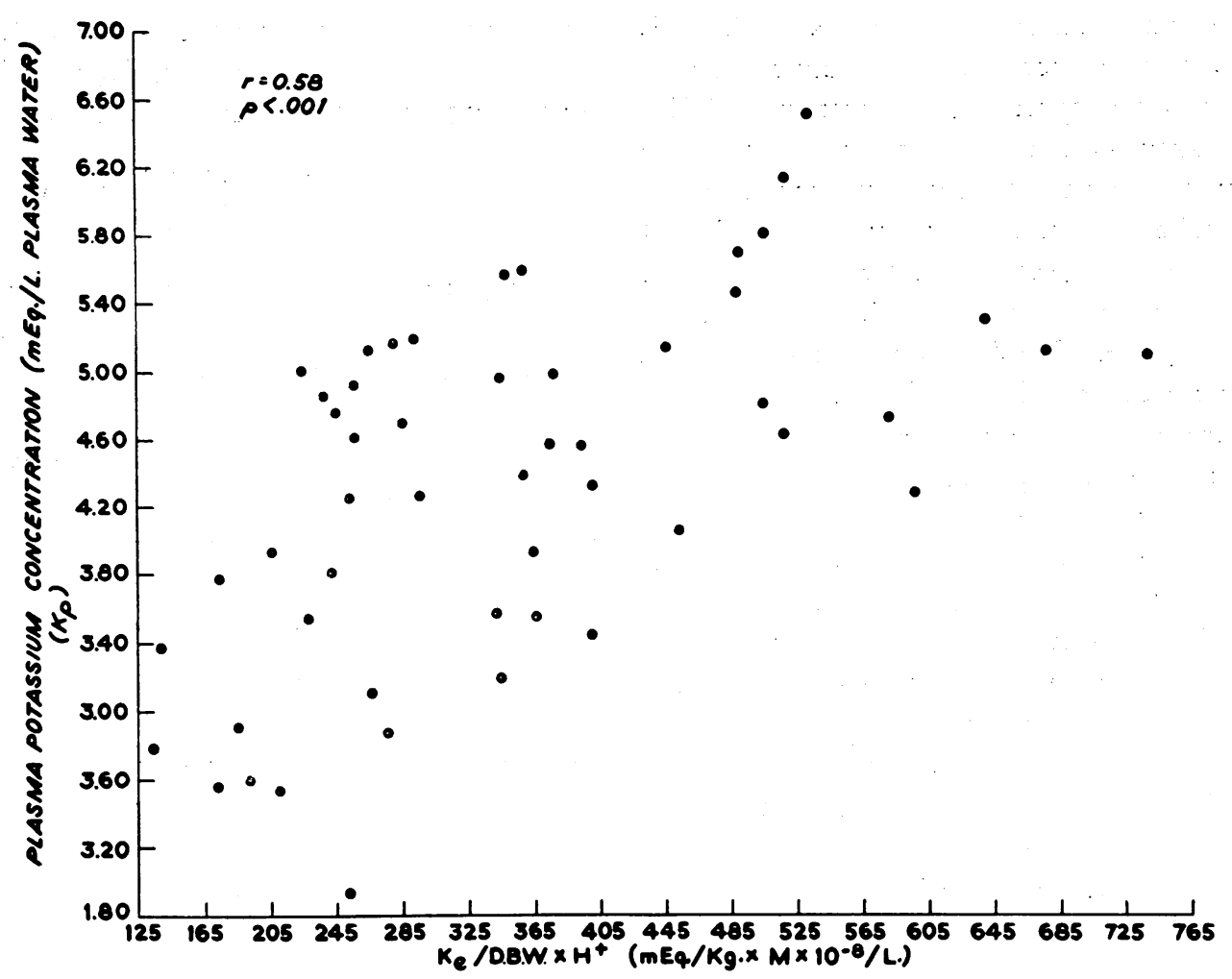

Fig. 3. Relation between Plasma Potassium Concentration $\left(K_{p}\right)$ and Product of Exchangeable Potassium per Kg. Dry Body Weight ( $K_{\circ} / D B W$ ) and Arterial Hydrogen Ion Concentration $\left(\mathrm{H}^{+}\right)$

found in this study between $\mathrm{K}_{\mathrm{p}}$ and $\mathrm{K}_{\mathrm{e}}$ /body weight was insignificant, $r=0.22$ (Table V). One possible reason for this lack of correlation may be the difficulty in quantitating body potassium in the presence of the variable amounts of body fat and water in disease states. An attempt to circumvent this problem was made, first by deliberate selection of lean subjects only for study, and second by measurement of TBW, thus allowing calculation of the artificial parameter "dry" body weight (DBW). In fact, $\mathrm{K}_{\mathrm{p}}$ did correlate significantly better with $\mathrm{K}_{\mathrm{e}} / \mathrm{DBW}(\mathrm{r}=0.39, \mathrm{p}<$ 0.005 ) than with $K_{e}$ /body weight (see Figure 2). In the subgroup with respiratory acid-base disturbances, $r=-0.28$ (see Table V). These imperfect correlations, while confirming the significant effect of alterations of body potassium content on $K_{p}$, attest to the need for a more comprehensive analysis of the factors affecting $\mathrm{K}_{\mathrm{p}}$, and again suggest that selective influences operate on $K_{p}$ in metabolic and respiratory acid-base disturbances.
Plasma potassium concentration, body content of potassium, and extracellular $\mathrm{pH}$

The almost invariable association of acid-base disturbances with those conditions which result in significant changes of body potassium content and $\mathrm{K}_{\mathrm{p}}$ implies the existence of some overall quantitative relationship between $K_{p}$, body potassium content, and extracellular $\mathrm{pH}$. Burnell, Scribner and co-workers $(1,2)$ have derived semiquantitative formulations which purport to define the relationships between changes in $K_{p}$ and body potassium content and changes in $\mathrm{K}_{\mathrm{p}}$ and extracellular $\mathrm{pH}$. These formulations are of some value clinically, but provide no integrated account of the determinants of $K_{p}$ at any one time. It seemed reasonable, therefore, to examine the proposition that the extracellular fluid $\mathrm{pH}$, or $\mathrm{H}_{\mathrm{a}}$, quantitatively controls the gradient of potassium concentration across the cell membrane in the steady state, i.e., in the absence of acute distorting factors such as changes in potassium balance. The simplest repre- 
sentation of this relationship is : $\mathrm{K}_{\mathrm{p}} / \mathrm{K}_{\mathrm{ic}}=\mathrm{k} \times \mathrm{H}_{\mathrm{a}}$ where $\mathrm{K}_{\mathrm{ic}}$ is the intracellular potassium concentration and $\mathrm{k}$ is a proportionality constant. If $\mathrm{K}_{\mathrm{e}} /$ DBW is taken as a measure of the intracellular potassium concentration (since extracellular potassium probably comprises no more than 3 to 4 per cent of exchangeable potassium) (45), then one may test experimentally the relationship: $\mathrm{K}_{\mathrm{p}}=\mathrm{k} \times \mathrm{H}_{\mathrm{a}} \times \mathrm{K}_{\mathrm{e}} / \mathrm{DBW}$. The correlation coefficient, $r$, for this relationship is $0.58(p<0.001)$ (see Figure 3), a modest improvement over the correlation between $\mathrm{K}_{\mathrm{p}}$ and $\mathrm{pH}$ alone. In the metabolic subgroup, the correlation coefficient for the relationship between $\mathrm{K}_{\mathrm{p}}$ and $\mathrm{H}_{\mathrm{a}} \times \mathrm{K}_{\mathrm{e}} / \mathrm{DBW}$ is 0.70 , an increase which parallels a similar increase in the correlation between $\mathrm{K}_{\mathrm{p}}$ and $\mathrm{pH}$ in this subgroup. However, the respiratory subgroup again demonstrates a poor correlation, $r=$ 0.20. The empirical observation that in some cases which did not correlate well the plasma sodium concentrations were abnormal, and the experimental observations cited previously, sug- gested the possibility that the ratio $\mathrm{H}_{\mathrm{a}}: \mathrm{Na}_{\mathrm{p}}$ might be more decisive in determining $\mathrm{K}_{\mathrm{p}}$ than $\mathrm{H}_{\mathrm{a}}$ alone. Accordingly we tested the expression:

$$
\mathrm{K}_{\mathrm{p}}=\frac{\mathrm{k} \times \mathrm{K}_{\mathrm{e}} / \mathrm{DBW} \times \mathrm{H}_{\mathrm{a}}}{\mathrm{Na}_{\mathrm{p}}}
$$

(see Figure 4). This maneuver resulted in still higher degrees of correlation, $r=0.62$ for the entire group, $r=0.74$ for the metabolic subgroup (see Figure 5) and $r=0.24$ for the respiratory subgroup. Logarithmic and semilogarithmic formulations did not materially modify any of the described statistical relationships.

\section{DISCUSSION}

Previous observations have indicated that changes in extracellular $\mathrm{pH}$, body potassium content, and plasma sodium concentration individually are associated with acute and chronic aberrations of plasma potassium concentration. The data obtained in this study show that plasma potassium

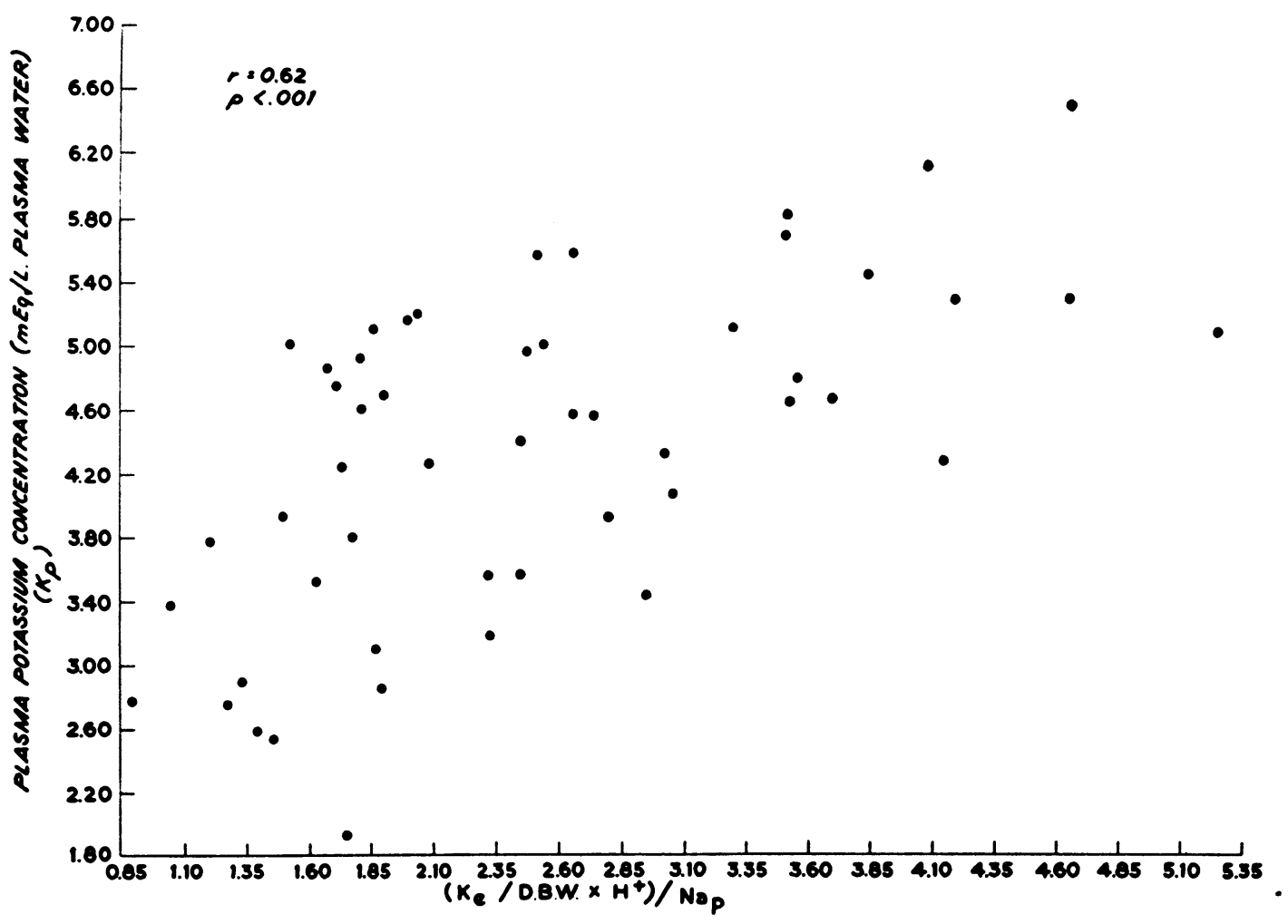

Fig. 4. Relation between Plasma Potassium Concentration $\left(K_{p}\right)$ and Ratio of Exchangeable Potassium per Kg. Dry Body Weight (Ke/DBW) $\times$ Arterial Hydrogen Ion Concentration $\left(\mathrm{H}^{+}\right.$) to Plasma Sodium Concentration $\left(\mathrm{Na}_{\mathrm{p}}\right)$ 


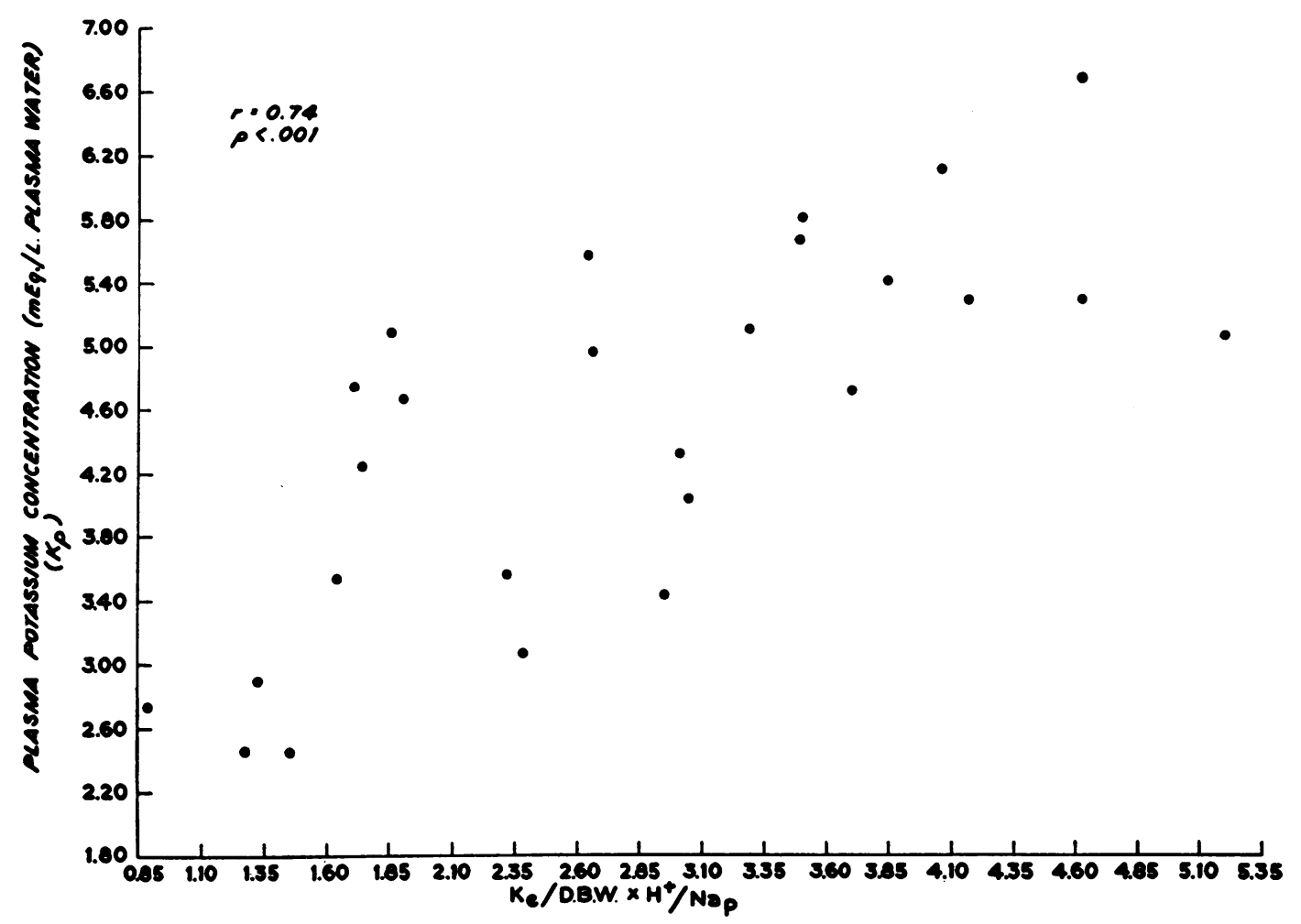

Fig. 5. Relation between Plasma Potassium Concentration ( $K_{p}$ ) and Ratio of Exchangeable Potassium per Kg. Dry Body Weight (K。/DBW) $\times$ Arterial Hydrogen Ion Concentration $\left(\mathrm{H}^{+}\right.$) to Plasma Sodium Concentration $\left(\mathrm{Na}_{\mathrm{p}}\right.$ ) in Patients with Metabolic Acid-Base Disturbances

concentration is related to these three factors in decreasing order of importance. A summary of statistical correlations is presented in Table V. Striking differences are apparent between metabolic and respiratory acid-base disturbances, in that $K_{p}$ seems much less dependent on these variables in the latter category (see Table V). A very close relationship $(r=0.74)$ has been found between $\mathrm{K}_{\mathrm{p}}$ and the ratio $\frac{\mathrm{H}_{\mathrm{a}} \times \mathrm{K}_{\mathrm{e}} / \mathrm{DBW}}{\mathrm{Na}_{\mathrm{p}}}$ in patients with metabolic acid-base disturbances. ${ }^{2}$ It may be inferred from these observations that additional factors or different mechanisms affect $K_{p}$ in patients with respiratory acid-base disturbances. This interesting finding suggests that $\mathrm{H}_{2}$ does not directly effect changes in $K_{p}$, but exerts its influence by its effects on intracellular buffering processes, and ultimately on intracellular hydrogen ion concentration. These effects probably depend on

\footnotetext{
2 The consistently improved correlation coefficient resulting from the inclusion of $\mathrm{Na}_{\mathrm{p}}$ in the denominator (although not statistically conclusive) strongly suggests that this observation is valid.
}

whether the primary disturbance is metabolic or respiratory in nature. Such a possibility is supported by Tobin's demonstration (43) that different degrees of acidosis and $K_{p}$ change could be induced by equal loads of mineral and organic acids and by Fenn and Cobb's experiment showing that under certain conditions raising the extracellular concentration of dissolved $\mathrm{CO}_{2}$ resulted in movement of potassium into cells (35). A possibly related factor may be the inherent lability of respiratory disturbances; the rapid diffusibility of $\mathrm{CO}_{2}$ into and out of cells in response to changes in ventilation may preclude the establishment of the steady state envisioned in this study.

The proposal that $\mathrm{K}_{\mathrm{p}}$ is proportional to the ratio $\frac{\mathrm{H}_{\mathrm{a}} \times \mathrm{K}_{\mathrm{e}} / \mathrm{DBW}}{\mathrm{Na}_{\mathrm{p}}}$ may be interpreted as having fundamental physiological significance, provided that simplifying assumptions are valid. This relationship may indicate the passive distribution of potassium and hydrogen ions in proportion to resting transmembrane potential differences, prob- 
ably modified by a Gibbs-Donnan equilibrium. Such a relationship may be represented by the expression: $\mathrm{K}_{\mathrm{p}} / \mathrm{K}_{\mathrm{ic}}=\mathrm{H}_{\mathrm{a}} / \mathrm{H}_{\mathrm{ic}}$, where "ic" denotes concentrations inside the cell. The experimental verification of this simple construct is hampered by the lack of accurate measures of $\mathrm{K}_{\mathrm{ic}}$ and $\mathrm{H}_{\mathrm{ic}}$. However, if the equation is rearranged, viz., $\mathrm{K}_{\mathrm{p}}=\frac{\mathrm{K}_{\mathrm{ic}} \times \mathrm{H}_{\mathrm{a}}}{\mathrm{H}_{\mathrm{ic}}}$, then a resemblance emerges to the formulation presented in this study, except that the factor $\mathrm{H}_{\mathrm{ic}}$ is replaced by $\mathrm{Na}_{\mathrm{p}}$ and $\mathrm{K}_{\mathrm{ic}}$ is approximated by $\mathrm{K}_{\mathrm{e}} / \mathrm{DBW}$.

If potassium and hydrogen ions are passively transported across cell membranes, then the magnitude and direction of their movements, as conditioned by both the Donnan equilibrium and the transmembrane potential, would be similar. If, however, potassium is actively transported into the cell, it is conceivable that hydrogen ion competes for transport sites in the membrane in a fashion analogous to the apparent competition of potassium and hydrogen for secretion into the distal tubular segment of the kidney (46). Such a process would also reveal a dependence of $K_{p}$ on $\mathrm{H}_{\mathrm{a}}$. A mechanism of this kind, however, would not in itself account for the differences noted in the correlations of $\mathrm{K}_{\mathrm{p}}$ with $\mathrm{pH}_{\mathrm{a}}$ between the group of patients with metabolic acid-base disturbances and the group with respiratory acid-base disturbances. The possible correspondence between $\mathrm{Na}_{\mathbf{p}}$ and $\mathrm{H}_{\mathrm{ic}}$ suggested above may arise from a dependency of intracellular osmolality on $\mathrm{H}_{\mathrm{ic}}$ analogous to the dependency of extracellular osmolality on $\mathrm{Na}_{\mathrm{p}}$, which has been verified experimentally (15).

The expression $\mathrm{K}_{\mathrm{e}} / \mathrm{DBW}$ provides only a gross estimate of intracellular potassium content based on separate measurements of $K_{e}$, body weight, and total body water. Despite selection of lean subjects only, variable quantities of body fat were unquestionably present. Considering the close correlation between $\mathrm{K}_{\mathrm{e}}$ and lean body mass it is probable that a measurably greater dependence of $K_{p}$ on the product of $\mathrm{H}_{\mathrm{a}}$ and body potassium content might be found if $\mathrm{K}_{\mathrm{e}}$ were expressed in units of lean body mass $(21,47)$. The high incidence of hepatic disease may have been a complicating factor in this group of patients; the liver probably participates in changes of $K_{p}$ during respiratory disturbances since the initial rise in $K_{p}$ in early respiratory alkalosis is abolished in hepatectomized animals $(9,41,48)$. The number of cases with respiratory disturbances was relatively small and it was not feasible to study any severe cases of this type. Finally there may be specific influences on $K_{p}$ such as the effects of epinephrine secretion or other hormonal factors which may alter potassium gradients across cell membranes independent of the effect of hydrogen ion or body potassium content $(40,49-51)$.

\section{SUMMARY}

The relationships of plasma potassium concentration $\left(\mathrm{K}_{\mathrm{p}}\right)$, plasma sodium concentration $\left(\mathrm{Na}_{\mathrm{p}}\right)$, extracellular fluid $\mathrm{pH}$, and body potassium content, expressed as exchangeable potassium per kilogram of dry body weight $\left(\mathrm{K}_{\mathrm{e}} / \mathrm{DBW}\right)$, were explored by simultaneous measurements in a heterogeneous group of chronically ill patients with a variety of acid-base disturbances.

Plasma potassium concentration correlates poorly or slightly with $\mathrm{Na}_{\mathrm{p}}$, plasma $\mathrm{pCO}_{2}$ and $\mathrm{K}_{\mathrm{e}} / \mathrm{DBW}$. A modest correlation exists between $K_{p}$ and arterial blood hydrogen ion concentration $\left(\mathrm{H}_{\mathrm{a}}\right)$ which is enhanced significantly when $\mathrm{K}_{\mathrm{p}}$ is plotted against $\frac{\mathrm{H}_{\mathrm{a}} \times \mathrm{K}_{\mathrm{e}} / \mathrm{DBW}}{\mathrm{Na}_{\mathrm{p}}}$. Striking differences in correlation appear between subgroups of patients with metabolic and respiratory acid-base disturbances. In the group of patients with metabolic disturbances a close correlation was found between $\mathrm{K}_{\mathrm{p}}$ and $\frac{\mathrm{H}_{\mathrm{a}} \times \mathrm{K}_{\mathrm{e}} / \mathrm{DBW}}{\mathrm{Na}_{\mathrm{p}}}$ which is not apparent in the group with respiratory acidbase disturbances.

The physiological implications of these findings are discussed, and possible differential mechanisms in these two types of acid-base disturbance are presented.

\section{REFERENCES}

1. Burnell, J. M., Villamil, M. F., Uyeno, B. T., and Scribner, B. H. The effect in humans of extracellular $\mathrm{pH}$ change on the relationship between serum potassium concentration and intracellular potassium. J. clin. Invest. 1956, 35, 935.

2. Scribner, B. H., and Burnell, J. M. Interpretation of the serum potassium concentration. Metabolism $1956,5,468$.

3. Scribner, B. H., Bogardus, G. M., Fremont-Smith, K., and Burnell, J. M. : Potassium intoxication 
during and immediately following respiratory acidosis (abstract). J. clin. Invest. 1954, 33, 965.

4. Scribner, B. H., and Burnell, J. M. The effect of respiratory alterations of $\mathrm{pH}$ on the internal equilibrium of potassium (abstract). J. clin. Invest. 1955, 34, 919.

5. Scribner, B. H., Fremont-Smith, K., and Burnell, J. M. The effect of acute respiratory acidosis on the internal equilibrium of potassium. J. clin. Invest. $1955,34,1276$.

6. Singer, R. B., Elkinton, J. R., Barker, E. S., and Clark, J. K. Transfers of cellular cations during acute respiratory alkalosis and acidosis experimentally produced in man (abstract). J. clin. Invest. 1953, 32, 604.

7. Stanbury, S. W., and Thomson, A. E. The renal response to respiratory alkalosis. Clin. Sci. 1952, $11,357$.

8. Elkinton, J. R., Singer, R. B., Barker, E. S., and Clark, J. K. Effects in man of acute experimental respiratory alkalosis and acidosis on ionic transfers in the total body fluids. J. clin. Invest. 1955, 34, 1671.

9. Joyner, S. B., Davis, D. A., Young, D. T., Craige, E., and Welt, L. G. An analysis of the chemical events and their interrelationships with alterations in the ECG during respiratory acidosis and alkalosis (abstract). J. clin. Invest. 1955, 34, 974.

10. Mackay, J. L. Effects of a narcotic level of carbon dioxide on the plasma potassium and respiration of cats. Amer. J. Physiol. 1947, $151,469$.

11. Young, W. G., Jr., Sealy, W. C., and Harris, J. S. The role of intracellular and extracellular electrolytes in the cardiac arrhythmias produced by prolonged hypercapnia. Surgery 1954, 36, 636.

12. Moore, F. D., Boling, E. A., Ditmore, H. B., Jr., Sicular, A., Teterick, J. E., Ellison, A. E., Hoye, S. J., and Ball, M. R. Body sodium and potassium. V. The relationship of alkalosis, potassium deficiency, and surgical stress to acute hypokalemia in man; experiments and review of the literature. Metabolism 1955, 4, 379.

13. Anderson, H. M., and Laragh, J. H. Renal excretion of potassium in normal and sodium depleted dogs. J. clin. Invest. 1958, 37, 323.

14. Moore, F. D. Common patterns of water and electrolyte change in injury, surgery and disease. New Engl. J. Med. 1958, 258, 277.

15. Edelman, I. S., Leibman, J., O'Meara, M. P., and Birkenfeld, L. W. Interrelations between serum sodium concentration, serum osmolarity and total exchangeable sodium, total exchangeable potassium and total body water. J. clin. Invest. 1958, 37, 1236.

16. Harris, J. E. Influence of metabolism of human erythrocytes on their potassium content. J. biol. Chem. 1941, 141, 579.

17. Sheppard, C. W., Martin, W. R., and Beyl, G. Cation exchange between cells and plasma of mammalian blood. II. Sodium and potassium exchange in sheep, dog, cow and man and effect of varying plasma potassium concentration. J. gen. Physiol. 1951, 34, 411.

18. Fox, C. L., Jr., and Baer, H. Redistribution of potassium, sodium and water in burns and trauma, and its relation to phenomena of shock. Amer. J. Physiol. 1947,151, 155.

19. Birkenfeld, L. W., Leibman, J., O'Meara, M. P., and Edelman, I. S. Total exchangeable sodium, total exchangeable potassium, and total body water in edematous patients with cirrhosis of the liver and congestive heart failure. J. clin. Invest. 1958, 37, 687.

20. O'Meara, M. P., Birkenfeld, L. W., Gotch, F. A., and Edelman, I. S. The equilibration of radiosodium $\left(\mathrm{Na}^{24}\right)$, radiopotassium $\left(\mathrm{K}^{2}\right)$ and deuterium oxide $\left(\mathrm{D}_{2} \mathrm{O}\right)$ in hydropic human subjects. J. clin. Invest. 1957, 36, 784.

21. Corsa, L., Jr., Olney, J. M., Jr., Steenburg, R. W., Ball, M. R., and Moore, F. D. The measurement of exchangeable potassium in man by isotope dilution. J. clin. Invest. 1950, 29, 1280.

22. Langham, W. H., Eversole, W. J., Hayes, F. N., and Trujillo, T: T. Assay of tritium activity in body fluids with use of a liquid scintillation system. J. Lab. clin. Med. 1956, 47, 819.

23. Sanderson, P. H. Potentiometric determination of chloride in biological fluids. Biochem. J. 1952, 52, 502.

24. Peters, J. P., and Van Slyke, D. D. Quantitative Clinical Chemistry, 2nd ed. Vol. II. Methods. Baltimore, The Williams \& Wilkins Co., 1946, p. 283.

25. Singer, R. B., and Hastings, A. B. Improved clinical method for estimation of disturbances of acidbase balance of human blood. Medicine-1948, 27, 223.

26. Schloerb, P. R., Friis-Hansen, B. J., Edelman, I. S., Solomon, A. K.; and Moore, F. D. The -measurement of total body water in the human subject by deuterium oxide dilution. With a consideration of the dynamics of deuterium distribution. J. clin. Invest. 1950, 29, 1296.

27. Snedecor, G. W. Statistical Methods Applied to Experiments in Agriculture and Biology, 5th ed. Ames, Iowa State College Press, 1956.

28. Mokotoff, R., Ross, G., and Leiter, L. The electrolyte content of skeletal muscle in congestive heart failure; a comparison of results with inulin and chloride as reference standards for extracellular water. J. clin. Invest. 1952, 31, 291.

29. Mudge, G. H., and Vislocky, K. Electrolyte changes in human striated muscle in acidosis and alkalosis. J. clin. Invest. 1949, 28, 482.

30. Talso, P. J., Spafford, N., and Blaw, M. Metabolism of water and electrolytes in congestive heart failure. II. Distribution of water and electrolytes in skeletal muscle in edematous patients with congestive heart failure before and after treatment. J. Lab. clin. Med. 1953, 41, 405. 
31. Riecker, G., and Bubnoff, M. von. Uber den intracellulären Wasser-und Elektrolytstoffwechsel ; Untersuchungen an Erythrocyten. II. Mitteilung : Ödemkrankheiten. Klin. Wschr. 1958, 36, 556.

32. Agna, J. W., and Knowles, H. C., Jr. Further studies on the erythrocyte concentration of potassium in conditions of hyponatremia and hypernatremia. J. Lab. clin. Med. 1958, 51, 359.

33. Orloff, J., Walser, M., Kennedy, T. J., Jr., and Bartter, F. C. Clinical Conference: Hyponatremia. Circulation 1959, 19, 284.

34. Laragh, J. H., and Capeci, N. E. Effect of administration of potassium chloride on serum sodium and potassium concentration. Amer. J. Physiol. 1955, $180,539$.

35. Fenn, W. O., and Cobb, D. M. The potassium equilibrium in muscle. J. gen. Physiol. 1934, 17, 629.

36. Keating, R. E., Weichselbaum, T. E., Alanis, M., Margraf, H. W., and Elman, R. The movement of potassium during experimental acidosis and alkalosis in the nephrectomized dog. Surg. Gynec. Obstet. 1953, 96, 323.

37. Swan, R. C., Axelrod, D. R., Seip, M., and Pitts, R. F. Distribution of sodium bicarbonate infused into nephrectomized dogs. J. clin. Invest. 1955, 34, 1795.

38. Swan, R. C., and Pitts, R. F. Neutralization of infused acid by nephrectomized dogs. J. clin. Invest. 1955, 34, 205.

39. Giebisch, G., Berger, L., and Pitts, R. F. The extrarenal response to acute acid-base disturbances of respiratory origin. J. clin. Invest. 1955, 34, 231.

40. Rapoport, S., Stevens, C. D., Engel, G. L., Ferris, E. B., and Logan, M. The effect of voluntary overbreathing on the electrolyte equilibrium of arterial blood in man. J. biol. Chem. 1946, 163, 411.

41. Hickam, J. B., Wilson, W. P., and Frayser, R. Observations on the early elevation of serum potas- sium during respiratory alkalosis. J. clin. Invest. 1956, 35, 601.

42. Tobin, R. B. Plasma, extracellular and muscle electrolyte responses to acute metabolic acidosis. Amer. J. Physiol. 1956, 186, 131.

43. Tobin, R. B. Varying role of extracellular electrolytes in metabolic acidosis and alkalosis. Amer. J. Physiol. 1958, 195, 685.

44. Moore, F. D., Edelman, I. S., Olney, J. M., James, A. H., Brooks, L., and Wilson, G. M. Body sodium and potassium. III. Inter-related trends in alimentary, renal and cardiovascular disease; lack of correlation between body stores and plasma concentration. Metabolism 1954, 3, 334.

45. Edelman, I. S., and Leibman, J. The anatomy of body water and electrolytes. Amer. J. Med. 1959, 27, 256.

46. Berliner, R. W., Kennedy, T. J., Jr., and Orloff, J. Relationship between acidification of urine and potassium metabolism. Effect of carbonic anhydrase inhibition on potassium excretion. Amer. J. Med. 1951, 11, 274.

47. Muldowney, F. P., Crooks, J., and Bluhm, M. M. The relationship of total exchangeable potassium and chloride to lean body mass, red cell mass and creatinine excretion in man. J. clin. Invest. 1957, $36,1375$.

48. Fenn, W. O., and Asano, T. Effects of carbon dioxide inhalation on potassium liberation from the liver. Amer. J. Physiol. 1956, 185, 567.

49. Brewer, G., Larson, P. S., and Schroeder, A. R. On the effect of epinephrine on blood potassium. Amer. J. Physiol. 1939, 126, 708.

50. Muirhead, E. E., Goth, A., and Jones, F. Sodium and potassium exchanges associated with nor-epinephrine infusions. Amer. J. Physiol. 1954, 179, 1.

51. O'Brien, G. S., Murphy, Q. R., Jr., and Meek, W. J. The effect of sympathomimetic amines on arterial plasma potassium and cardiac rhythm in anesthetized dogs. J.Pharmacol. exp. Ther. 1953, 109, 453. 